\title{
Europa i Rio - Verden i krisen
}

\section{Lykke Friis}

\section{Topmødet lagde vigtige spor ud for fremtiden, men det ændrer ikke ved, at mange satte spørgs- målstegn ved, om det havde været umagen værd. Og Europa bør drage konsekvenserne af, at Rio endnu engang har vist, hvor vanskeligt det er at vinde fodfæste i den nye multipolære verden}

"Alt bliver godt til sidst, og hvis alt ikke er godt endnu, er det bare fordi, vi ikke er kommet til afslutningen endnu". Armeret med dette brasilianske ordsprog drog 50.000 deltagere med over 120 stats- og regeringschefer i juni til bæredygtighedstopmødet i Rio de Janeiro. Men reelt sluttede topmødet, før det gik i gang, da ikke mindst de brasilianske værter var mere interesseret $i$ at afslutte topmødet med en fælles tekst frem for at opnå konkrete resultater til gavn for klimaet. Som EU's klimakommissær Connie Hedegaard udtrykte det på sin 'Twitter', var det netop "sigende, at ingen i lokalet var glade, da Rio-teksten blev vedtaget. Så svag er den”. Hermed føjede Rio-topmødet sig til den lange liste af eksempler på, hvor vanskeligt det er at træffe afgørende multilaterale beslutninger i en multipolær verden, hvor Europas indflydelse er på kraftig retur.

\section{Tyve år efter Rio}

Rio+20 mødets hovedformål var at følge op på den milepæl, som verdens ledere satte for tyve år siden $\mathrm{i}$ Rio. Her lykkedes det for første gang verdens ledere at få bæredygtighed på den globale dagsorden, samtidigt med at de blev enige om to nye rammekonventioner om henholdsvis klima (UNFCCC) og biodiversitet $(\mathrm{CBD})$. Trods de konkrete fremskridt i Rio og indsatsen efterfølgende er opgaven mildest talt 
ikke blevet mindre siden 1992. Det hænger ikke mindst sammen med den voldsomme befolkningsstigning og de mange nye vækstøkonomier, såsom Kina og Indien, der for alvor har gjort deres entre som storforbrugere af alt lige fra vand til energi. Konkret viser beregninger, at verdens efterspørgsel efter energi i 2030 vil stige med 40 pct, mens efterspørgslen efter vand og fødevarer vil stige med henholdsvis 30 og 40 pct.

Da ikke mindst indvinding af de fossile brændsler har svært ved at følge trop med efterspørgslen, har kampen om ressourcerne allerede udviklet sig til en destabiliserende faktor i verdenspolitikken. Adgang til billig energi er blevet til en selvstændig magtfaktor, ligesom fx fødevarekrisen i 2007-8 førte til protester og opstande i over 60 lande.

Den konkrete opgave, der skulle håndteres på det nye topmøde i Rio, var derfor til at få øje på: hvordan kan verden både gennemføre en transformation fra fossile brændsler til grøn energi og sikre, at den stærkt stigende befolkning bliver brødfødt?

\section{Vanskelige startvilkår}

Bagtæppet for Rio-topmødet gav mildest talt ikke anledning til optimisme. Ligesom allerede på klimatopmøderne i København, Cancun og Durban bevirker den økonomiske krise, at mange lande fokuserer på den såkaldte korte bane frem for allerede nu at forberede verden på de problemer, der uundgåeligt venter forude. Ganske karakteristisk valgte nogle af verdens absolutte topledere såsom præsident Obama og kansler Merkel helt at blive hjemme fra Rio. Dertil kom, at topmødeoptakten var præget af en klassisk 'nulsumslogik', hvor udviklingslandene frygter, at de er kommet for sent til 'vækstfesten', og at der nu skal lægges låg på deres vækstmuligheder.

I praksis frygter mange udviklingslande tillige, at Vestens insisteren på 'grøn økonomi' blot er en eufemisme for protektionisme, hvor produkter kan blive holdt ude fra markeder under henvisning til bestemte klima- og miljøstandarder. Sidst men ikke mindst kompliceredes forhandlingerne af, at G-77 gruppen mildest talt ikke er en homogen gruppe. Det så man allerede i København, hvor G-77, der spænder fra Mali til Singapore over Indien og Kina, havde mere end svært ved at blive enige.

\section{Storpolitisk matchfixing}

Modsat de seneste klimatopmøder var Rio+20-topmødet karakteriseret ved, at der stort set ikke var nogle forhandlinger. Frem for den klassiske dramatik, hvor urene blev sat $\mathrm{i}$ stå, og ministre gik i separate arbejdsgrupper om natten for at finde de nødvendige kompromiser, vandrede ministre hvileløst rundt i det store konferencecenter uden at 
komme i kamp. Rio+20 kom hermed til at minde om storpolitisk matchfixing, hvor mellemmænd (læs embedsmænd), inden ministrene ankom, havde aftalt, at kampen skulle ende $0-0$.

Det bemærkelsesværdige var ikke så meget, at stats- og regeringscheferne endte med at blive statister. Tværtimod. Det var ifølge brasilianerne én af de vigtige lærer fra COP15 i København - sæt aldrig stats- og regeringschefer til at lave avanceret gruppearbejde! Nej, det bemærkelsesværdige lå i, at ikke engang ressortministrene, altså miljøministrene, blev bænket ved forhandlingsbordet. Allerede den 18. juni lagde Brasiliens udenrigsminister Antonio Patriota nemlig en tekst på bordet - en tekst, som med ganske få ændringer blev vedtaget den 19. juni; altså dagen før, at det såkaldte højniveausegment med stats- og regeringschefer og ministre skulle gå i gang.

Teksten var i høj grad udtryk for den laveste fællesnævner, hvor forhandlingsproblemer konsekvent blev løst ved at udvande teksten. Som allerede næunt var Brasiliens hovedmålsætning, at topmødet bare skulle afsluttes med et slutdokument, samtidigt med at landet på forhånd havde planlagt en række 'roundtables' om fx energi, som efter planen i sig selv skulle generere ny momentum og inspirere lande til at gennemføre nye grønne planer, når Rio var overstået. "Fokuser nu ikke kun på forhandlingssporet; der er også et handlingsspor", lød det igen og igen fra brasilianerne.

Den uambitiøse forhandlingstaktik faldt i god jord hos de øvrige BASIC-lande (Kina, Indien og Sydafrika), der ikke var interesseret i nye internationale bindinger. Det samme gjaldt USA, hvor valgåret nærmest umuliggjorde, at de amerikanske forhandlere kunne bevæge sig en tomme. Hermed var EU, ud over naturligvis mange afrikanske lande og østaterne, reelt den eneste spiller, der ønskede en ambitiøs aftale, hvilket i sig selv svækkede EU's position. Som bekendt er det nemlig meget vanskeligt at smække med døren, når man brændende ønsker sig at gå ind ad den!

EU's gennemslagskraft blev desuden markant svækket af gældskrisen. Hvor det tidligere var de europæiske lande, der bidrog til den internationale monetære valutafond (IMF), står EU i dag med hatten i hånden og samler penge ind til den europæiske redningsfond (EFSF/ ESM). Ikke mindst kontrasten i forhold til Brasilien var til at få øje på. I 1999 bidrog Europa til den sidste brasilianske hjælpepakke; i 2012 er Brasilien nettobidragsyder til IMF og besluttede på det G20-møde, der fandt sted i dagene før Rio, at øge hjælpen til IMF - en hjælp, der bl.a. går til EU. Netop nødvendigheden af at bede om økonomisk hjælp udefra fik europæernes mange taler om det rentable i 'grøn økonomi' til at 
fremstå temmelig hule. Situationen blev bestemt ikke bedre af, at Angela Merkel drog direkte hjem fra G20-mødet i Mexico for at koncentrere sig 100 pct om euroens redning. Eller for at sætte det på spidsen: grøn økonomi og bæredygtighed fremstod som en disciplin, som også europæerne lige måtte udskyde til bedre tider!

Da det i modsætning til især COP15 i København, men også COP16 i Cancun og COP17 i Durban, ikke var lykkedes at skabe et egentlig pres på verdens ledere, var der reelt ingen, der frygtede at gå ud til verdenspressen og NGO-miljøet efterfølgende og meddele, at Rio+20-forhandlingerne nu var afsluttede. Ganske symptomatisk fyldte G20-mødet og det efterfølgende EU-topmøde om gældskrisen langt mere i verdens avisspalter. Kort sagt: ingen regeringsledere behøvede at være nervøse for at blive udstillet som global 'Spielverderber'.

Netop pga. det manglende pres og brasilianernes klare taktik om slet ikke at forsøge at skabe et nattedrama, hvor ministrene kunne blive aftvunget kompromiser - opgav de ankomne ministre hurtigt at genåbne teksten. Storbritanniens vicepremierminister Nick Clegg udtrykte det på følgende måde: "Der var et tidspunkt, hvor vi tænkte, 'er det her så langt under vore forventninger, at vi skal trække stikket?'... men, hvis vi prøvede at genåbne Pandoras æske, ville vi nok ikke være kommet frem til et bedre resultat”. Og han fortsatte: "...uanset om det er Indiens bekymring for, at 'grøn økonomi' er en eufemisme for protektionisme eller Kinas bekymring for nogle af de forpligtelser, som de skal indfri, så er disse stemmer blevet meget stærkere, og det er den nye, langt mere komplekse verden, vi lever i”.

\section{Rio minus 20}

Rio-teksten blev ikke overraskende mødt af massiv kritik fra de internationale NGO'er. Fx omdøbte Greenpeaces repræsentant aftalen til 'Rio minus 20', mens andre gjorde sig umage med at foretage en simpel optælling af, hvor mange gange stats- og regeringscheferne brugte udtryk som 'encourage' (50) og 'support' (99) i forhold til 'must' (3).

En god illustration af dette er topmødetekstens afsnit om udfasning af statsstøtten til de fossile brændsler, hvor stats- og regeringscheferne blot 'genbekræfter' G20-landenes beslutning fra før COP15 og 'inviterer' andre lande til at følge trop. Norges tidligere statsminister og frontfigur for FN's Miljø- og Udviklingskommission Gro Harlem Brundtland pegede på, at teksten sågar på i hvert fald ét område, nemlig den manglende omtale af kvinders reproduktive rettigheder, fremstod som et decideret tilbageslag.

Trods NGO'ernes skuffelse er der dog ingen tvivl om, at topmødet 
også lagde nogle vigtige spor ud for fremtiden. Det gælder ikke mindst beslutningen om, at der i 2015 skal vedtages bæredygtighedsmål (SDG), som skal supplere de oprindelige 'Millennium Development Goals' (MDGs). Af andre fremskridt kan nævnes beslutningen om at styrke UNEP (FN's miljøorganisation) og udvikle et nyt såkaldt grønt BNP.

Alt dette ændrer dog ikke ved, at mange også satte spørgsmålstegn ved, om mødet overhovedet havde været umagen værd, og om verden ikke efter Rio skulle tage FN-forhandlingsmetoden med de store topmøder op til revision. Et godt eksempel er her Tysklands udviklingsminister Dirk Niebel: "Forhandlingerne om Rio+20 har vist, at vi også må tænke over nye formater, hvorved vi kan opnå resultater på internationalt plan. Det er nødvendigt at inddrage repræsentanter fra civilsamfundet, parlamenter og de store byer". Hans kollega, miljøminister Peter Altmaier, fulgte trop ved at plædere for, at Europa fremadrettet i stigende grad skulle satse på at etablere ' $a$ coalition of the willing' frem for at lade de mindst ambitiøse lande blokere for fremskridt.

Skal dette lykkes, kræver det imid- lertid, at EU får mere styr på gældskrisen. Ellers kan det blive svært for EU at trække på eksemplets magt inden for grøn økonomi. Og hvad der er mindst lige så vigtigt. Europa bør også drage konsekvenserne af, at Rio endnu engang har vist, hvor vanskeligt det er at vinde fodfæste i den nye multipolære verden med Kina, Indien osv.

Det var da også en af konklusionerne i det 'midtvejs-papir', som Tysklands udenrigsminister Guido Westerwelle offentliggjorde, efter at han på en række møder havde diskuteret Europas fremtid med ni kolleger, herunder Villy Søvndal: "Vi europæere vil kun være i stand til at hævde vore værdier og forsvare vore interesser effektivt over for de nye kraftcentre, hvis vi puljer vores styrker meget mere både internt, og når vi forhandler med resten af verden. Vi må adressere dette spørgsmål seriøst, da det er afgørende for vor fremtid. Vi står over for en historisk opgave i at sikre, at Europa bliver en global spiller".

Lykke Friis er formand for Det Udenrigspolitiske Selskab, medlem af Folketinget for Venstre og tidligere klima- og energiminister. 